\title{
XRCC2 Gene Mutation
}

National Cancer Institute

\section{Source}

National Cancer Institute. XRCC2 Gene Mutation. NCI Thesaurus. Code C157463.

A change in the nucleotide sequence of the XRCC2 gene. 